\title{
A Case of Endoscopic Management of Dacryocystocele in an Adult
}

\author{
Sung-Il Cho, Nam-Yong Do, Seung-Woo Yu and Ji-Yun Choi \\ Department of Otorhinolaryngology-Head and Neck Surgery, Chosun University College of Medicine, Gwangju, Korea
}

\section{내시경적 치료를 통해 치료한 성인 비루관 점액종 1 예}

조성일·도남용·유승우·최지윤

조선대학교 의과대학 이비인후과학교실

\author{
Received October 16, 2009 \\ Revised February 9, 2010 \\ Accepted February 23, 2010

\section{Address for correspondence} \\ Ji-Yun Choi, MD \\ Department of Otorhinolaryngology- \\ Head and Neck Surgery, Chosun \\ University College of Medicine, \\ 588 Seoseok-dong, Dong-gu, \\ Gwangju 501-717, Korea \\ Tel $+82-62-220-3200$ \\ Fax +82-62-225-2702 \\ E-mail happyent@naver.com
}

Dacryocystocele presents as a distended lacrimal sac and it is often considered to have a congenital etiology. However, dacryocystocele is an uncommon disease in adults. The clinical feature associated with a dacryocystocele is painless swelling at the site of the lacrimal sac, and this is usually found inferior to the medial canthal ligament. The lacrimal excretion test, endoscopy, CT scans and MRI are used to make the diagnosis of dacryocystocele. The management of a congenital dacryocystocele is conservative treatment that involves the use eye drops, lacrimal sac massage, lacrimal probing and surgery in some cases. However, for a dacryocystocele that develops in an adult, the dilated lacrimal sac does not decrease in size, so a nasal drainage procedure is the treatment of choice. We encountered an adult patient who presented with a dacryocystocele with an intranasal cystic mass, which we treated by endoscopic marsupialization. We report on this case along with a review of the related literature.

Korean J Otorhinolaryngol-Head Neck Surg 2010;53:306-9

Key Words Nasolacrimal duct $\cdot$ Mucocele $\cdot$ Adult.

\section{서 론}

비루관 점액종은 눈물관 배액 구조의 근위부와 원위부에 발생하는 드문 질환으로 주로 신생아에서 발생하며 성인에 서 발견되는 예는 매우 드물다. ${ }^{1)}$ 지금까지 성인에서의 국내 보고는 안과학회지에 한번 보고된 예가 있으나 이비인후과 에 보고된 바는 없다. ${ }^{2}$ 비루관 점액종은 무통성 누낭 팽창 증의 형태로 나타나며 주로 내안검 인대(medial canthal ligament) 아래 부위에서 발견되고, 선천성 비루관 점액종의 경우에는 원위부 비루관의 폐쇄와 기능적 근위부 폐쇄에 의해 발생된다. ${ }^{3)}$ 성인에서 비루관 점액종이 나타나는 경우 도 이와 비슷하며 주로 만성적인 원위부 폐쇄가 원인이 되 어 로젠뮬러관(Rosenmuller's valve) 부위의 만성적인 염 증으로 인해 점막이 부어오르고 이것이 눈물주머니의 배액 을 방해하기 때문이다. ${ }^{4)}$ 최근 저자들은 좌측 내안각 부위
의 염증성 종물을 주소로 내원하여 비루관 점액종으로 진 단되어 내시경적 치료를 시행한 예를 치험하였기에 문헌고 찰과 함께 보고하고자 한다.

\section{증 례}

45세 남자 환자가 1 년 전부터 시작된 좌측 내안각 부위 의 종괴와 유루현상을 주소로 내원하였다. 최근 내안각 부 위의 부종과 함께 압통이 발생하였으며 간헐적으로 좌측의 코막힘이 있었다. 과거력상 고혈압으로 약물을 복용 중이 었으며 그 외 수술 및 외상의 병력은 없었다. 가족력은 특 이사항이 없었다. 이학적 소견상 좌측 내안각 부위에 붉은 색의 약 $1 \mathrm{~cm}$ 정도의 단단한 종괴가 관찰되었으며 압통이 동반되었다. 비 내시경 소견상 중비갑개 안쪽의 중비도 내 에 표면이 매끈한 폴립양상의 약 $1.5 \mathrm{~cm}$ 크기의 종괴가 
관찰되었다(Fig. 1). 부비동 전산화단층촬영에서 비루관 내 에 약 $2.3 \times 1.0 \mathrm{~cm}$ 크기의 주변과 비교적 잘 구분되는 저 음영의 비교적 균등한 밀도를 가진 둥근형태의 종물이 관 찰되었으며 주위 골조직의 침윤 소견이 함께 관찰되었다. 이는 좌측 안와의 내안각 부위부터 비루관 내까지 위치하 면서 비루관을 확장시키는 소견이었다(Fig. 2). 전신마취 하 비내시경으로 비강 내 접근을 통해 조대술을 시행하였 다. 수술 중 낭종 내에 끈근한 점액성의 액체가 가득차 있 는 것이 관찰되었다(Fig. 3). 조대술 후 $1 \mathrm{~cm}$ 정도 넓어 진 비루관의 입구를 관찰할 수 있었고, 비루관 내의 점막 은 잘 보전되어 있었으며 비루관 입구 주변의 비강 외측 벽의 점막도 손상되지 않아 스텐트는 삽입하지 않았다. 술 후 비루관 세척시 세척액이 잘 통과하는 것을 확인하고 수

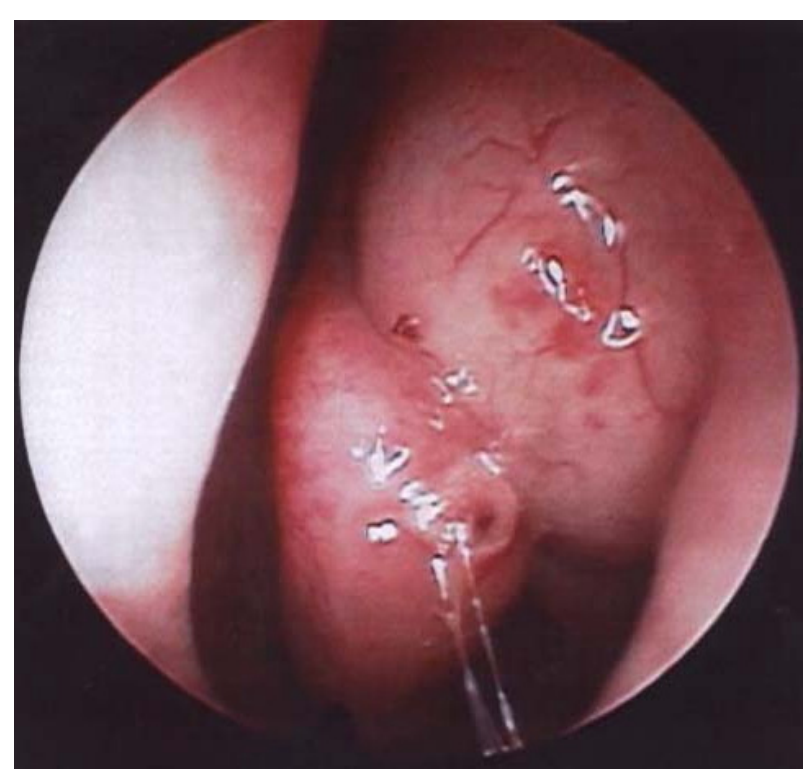

Fig. 1. Preoperative nasal endoscopy showing a dacryocystocele in the middle meatus.
술을 마쳤다. 조직검사상 점액종으로 판명되었고(Fig. 4) 술 후 1 년이 지난 현재까지 재발 소견은 관찰되지 않고 있 다(Fig. 5).

\section{고 찰}

비루관 점액종은 주로 내안검인대 (medial canthal ligament) 아래 부위에서 무통성의 종괴로 발견되고 비루관 하 부의 낭성 변화와 함께 비강 내로의 확장을 일으키는 질환 이다. 선천성 비루관 점액종의 경우에는 원위부 비루관의 폐쇄 또는 기능적 근위부 폐쇄에 의해 나타나게 된다. 성 인에서 비루관 점액종이 나타나는 경우도 이와 비슷하며 주로 만성적인 원위부 패쇄에 의해 일어나게 되고 이는 로 젠뮬러관 부위의 만성적인 염증 및 점막부종을 야기시키고

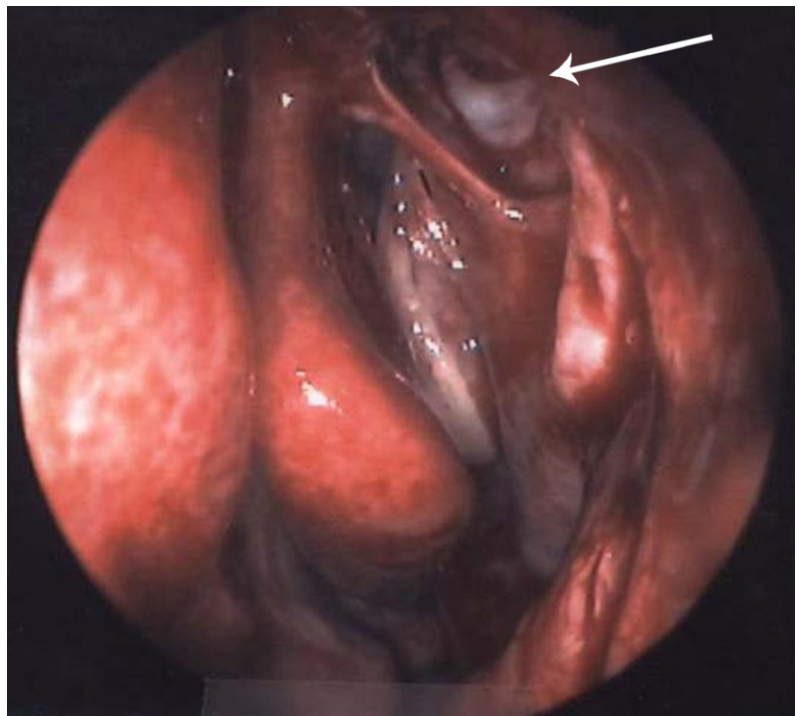

Fig. 3. Intraoperative nasal endoscopy showing the dacryocystocele (arrow) after endoscopic marsupialization.

Fig. 2. Preoperative axial CT shows a $2.3 \times 1.0 \mathrm{~cm}$ sized round cystic mass at NLD with adjacent bony erosion (A). Preoperative coronal CT shows a mass in the inferomedial aspect of the left orbit extends through a widened nasolacrima canal (B). NLD: nasolacrimal duct.
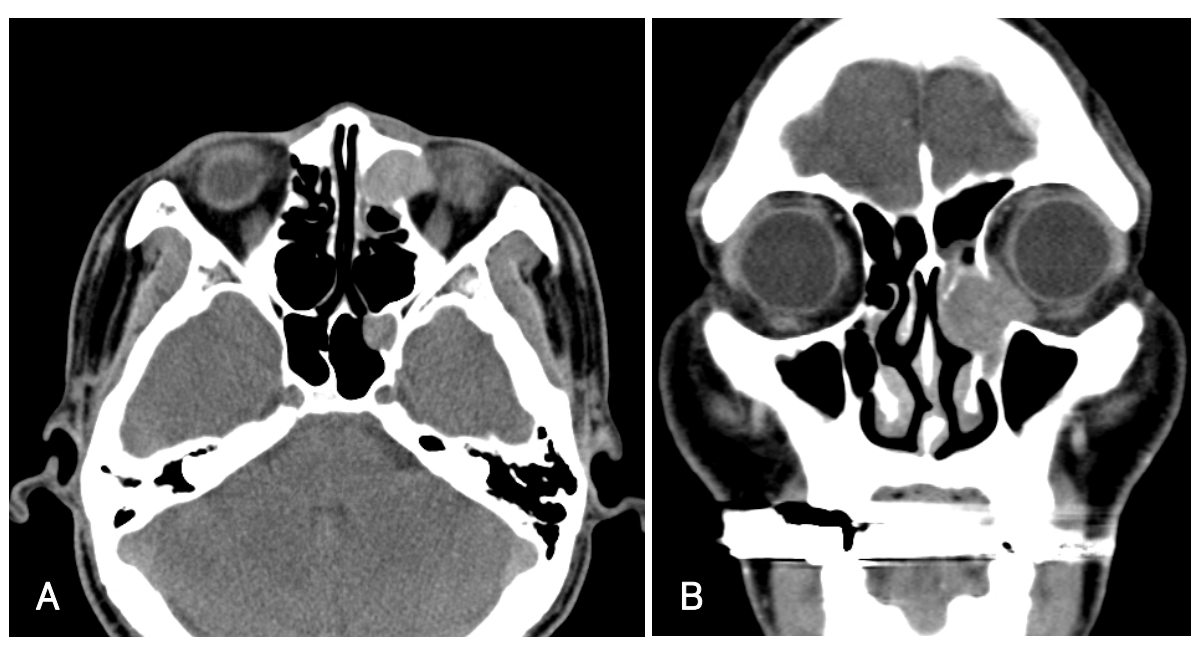


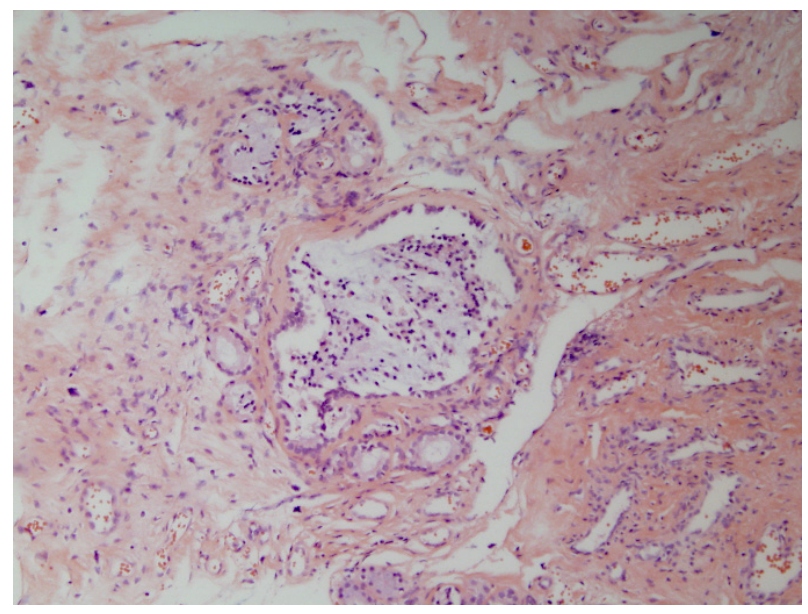

Fig. 4. Microscopically, glandular structure are lined by mucous secreting cells, stroma has edematous and myxoid fibrous tissue (H\&E, $\times 40)$.

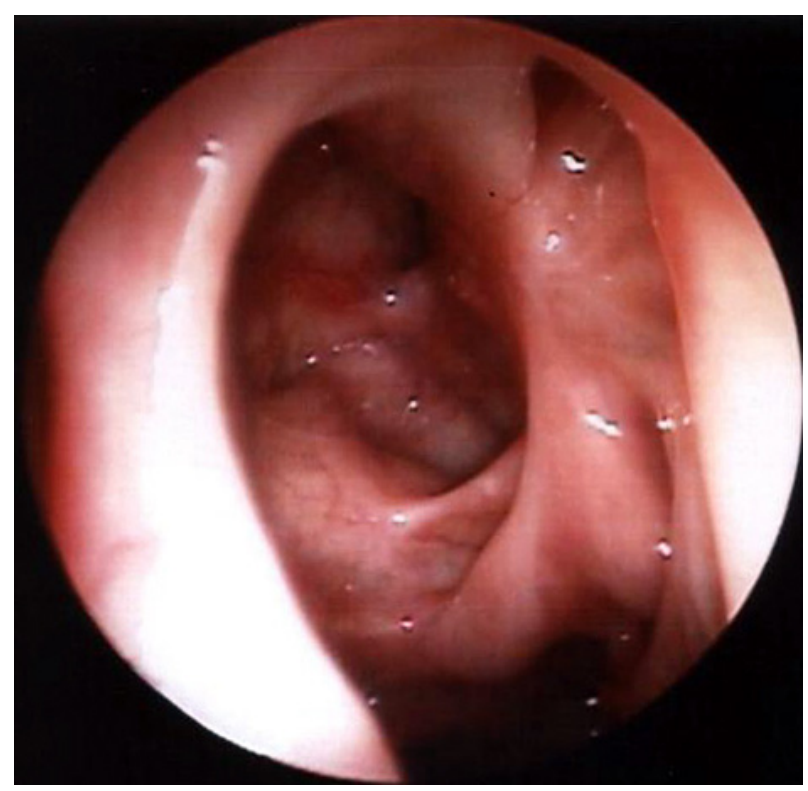

Fig. 5. Endoscopic finding at postoperative 1 year. It shows no evidence of recurrence in left nasal cavity.

이로 인해 역류성 배액이 억제되고 눈물소관을 전위 및 폐 쇄시켜 비루관 점액종이 형성된다. 선천성 눈물점 폐쇄도 하 나의 원인이다. 선천성 눈물점 폐쇄는 다른 기형을 자주 동 반하는데, 비루관 원위부의 폐쇄가 함께 발생하면 비루관 점액종이 발생하게 된다. ${ }^{4,5)}$

주 증상으로는 내안각의 무통성 종괴와 환측의 유루증이 나타날 수 있으며, 특히 어른에서 외측 부종으로 눈물소관 전위와 눈물점 폐쇄 소견을 보인다. 비루관 낭종의 진단은 주로 눈물샘을 가볍게 눌렀을 때 눈물점을 통한 분비물을 확인하거나 플루오르세인(fluorescein)을 결막낭에 떨어 뜨린 후 이것이 2 5분 후 사라지는가를 보는 비루관 배 출검사(lacrimal excretion test)와 누낭조영술, 경성, 연성
비내시경, 컴퓨터 전산화단층촬영, 자기공명영상으로 비루 관 확장, 점막하 비강내 종양을 발견하는 것으로 이루어진 다. 전산화단층촬영에서 비루관 점액종은 저음영의 중심부 를 얇은 막으로 둘러싸고 있는 경계가 분명한 낭성 종괴로 관찰되며 종괴의 경계만 조영되는데, 내안각의 낭성종괴, 비루관 확장, 비강 종괴로의 이행으로 진단할 수 있다. 자 기공명영상촬영은 진단에는 전산화단층촬영보다 우위에 있 으나 비강내 다른 병변을 알 수 없으므로 대부분 전산화단 층촬영을 시행한다. DelGaudio와 Wojno ${ }^{6)}$ 는 눈물흘림을 주 소로 내원한 모든 환자에게 내시경을 이용한 하비도검사가 필요하며 이를 통해 비루관 점액종을 쉽게 발견할 수 있다 고 하였으며, 비루관 세척이나 부지법을 동시에 시행하면 진 단에 도움이 된다고 하였다. Sasaki 등ㄱ)은 누낭내시경을 이용한 누낭 내 검사와 비내시경을 이용한 하비도검사를 동 시에 시행하면 진단 및 치료에 도움이 된다고 하였다.

치료는 선천성인 경우 증상이 심하지 않으면 마사지나 항생제 점안액 같은 보존적인 치료를 하면서 지켜보다가 확장된 눈물주머니가 원래의 크기로 돌아오지 않으면 수술 적 치료를 시행하게 된다. 반면 성인에서는 확장된 비루관 의 회복이 불가능하기 때문에 코안쪽으로 배출시키는 수술 적 치료를 먼저 고려해야 한다. 수술적 처치로는 내시경을 이용한 누낭비강 문합술(dacryocystorhinostomy), 비루 관 부지법(naso-lacrimal duct probing), 실리콘관 삽입술 (silicone intubation), 내시경적 조대술 등을 시행할 수 있 다. ${ }^{8-15)}$ 비루관 점액종이 근위부에 존재하거나 비강 내로 확장되지 않고 상악골 내에 존재하여 주변이 뼈에 의해 둘 러 쌓여있는 경우에는 누낭비강 문합술을 시행하고 비강 내 로 확장되어 비루관의 원위부가 단지 연부조직으로 덮혀있 는 경우에는 비강 내로 접근하여 내시경을 이용한 조대술 을 시행하며 비루관 내의 점막 및 비강외측 벽 입구주위의 점막이 손상되었을 경우에는 실리콘관 삽입술이 추가로 필 요하리라 사료된다. 과거에는 누낭비강 문합술을 주로 시 행하였으나 근래에는 내시경을 이용한 수술법이 발달하면 서 내시경적 조대술이 주로 시행되고 있으며 비루관 원위 부의 입구가 넓고 잘 딿려있는 경우에는 스텐트를 삽입하 지 않는다. Yamasoba와 Sugimura ${ }^{13)}$ 는 누낭비강 문합술 로 치료하였으며, Thimothy ${ }^{3)}$ 는 내시경적 조대술과 스텐트 를 이용해 치료하였고, Eloy 등 ${ }^{14)}$ 은 내시경적 조대술을 이 용하여 치료하였다.

지금까지 국내에서는 신생아 및 소아에서 그 발생이 보고 되어 왔으나 ${ }^{16-18)}$ 저자들은 성인에서 내원 1년 전부터 발 생한 비루관 점액종을 내시경적 조대술로 치료하여 재발 소 견 없이 좋은 결과를 보였기에 문헌고찰과 함께 보고하는 
바이다. 또한 눈물흘림을 주소로 내원한 모든 환자에게 비 내시경을 이용한 비강 내 검사가 진단에 도움이 되며 비강 내 접근을 통한 내시경수술이 비침습적이면서도 좋은 결과 를 보일 것으로 사료된다.

\section{Acknowledgments}

This study was supported by research funds from Chosun University, 2010.

\section{REFERENCES}

1) Weinstein GS, Biglan AW, Patterson JH. Congenital lacrimal sac mucoceles. Am J Ophthalmol 1982;94 (1):106-10.

2) Woo KI, Kim YD. Four cases of dacryocystocele. Korean J Ophthalmol 1997;11 (1):65-9.

3) Yip CC, McCulley TJ, Kersten RC, Bowen AT, Alam S, Kulwin DR. Adult nasolacrimal duct mucocele. Arch Ophthalomol 2003;121 (7): 1065-6.

4) Bhaya M, Meehan R, Har-El G. Dacryocystocele in an adult: endoscopic management. Am J Otolaryngol 1997;18 (2):131-4.

5) Sevel D. Development and congenital abnormalities of the nasolacrimal apparatus. J Pediatr Ophthalmol Strabismus 1981;18 (5) :13-9.

6) DelGaudio JM, Wojno T. Nasolacrimal duct orifice cysts in adult: a previously unrecognized, easily treatable cause of epiphora. Laryngoscope 2007; 117 (10):1830-3.

7) Sasaki T, Nagata Y, Sugiyama K. Nasolacrimal duct obstruction classified by dacryoendoscopy and treated with inferior meatal dacryorhinotomy. Part 1: positional diagnosis of primary nasolacrimal duct obstruction with dacryoendoscope. Am J Ophthalmol 2005;140 (6) 1065-9.

8) Roy D, Guevara N, Santini J, Castillo L. Endoscopic marsupialization of congenital nasolacrimal duct cyst with dacryocoele. Clin Otolaryngol Allied Sci 2002;27 (3):167-70

9) Levin AV, Wygnanski-Jaffe T, Forte V, Buckwalter JA, Buncic JR Nasal endoscopy in the treatment of congenital lacrimal sac mucoceles. Int J Periatr Otorhinolaryngol 2003;67 (3) :255-61.

10) Paysse EA, Coats DK, Bernstein JM, Go C, de Jong AL. Management and complications of congenital dacryocele with concurrent intranasal mucocele. J AAPOS 2000;4 (1):46-53

11) Shashy RG, Durairaj VD, Holmes JM, Hohberger GG, Thompson DM, Kasperbauer JL. Congenital dacryocystocele associated with intranasal cysts: diagnosis and management. Laryngoscope 2003; $113(1): 37-40$.

12) Jin HR, Shin SO. Endoscopic marsupialization of bilateral lacrima sac mucoceles with nasolacrimal duct cysts. Auris Nasus Larynx 1999; $26(4): 441-5$.

13) Yamasoba $T$, Sugimura $H$. Nasolacrimal drainage system cyst in an adult. ORL J Otorhinolaryngol Relat Spec 1996;58 (6) :311-4.

14) Eloy P, Martinez A, Leruth E, Levecq L, Bertrand B. Endonasal endoscopic dacryocystorhinostomy for a primary dacryocystocele in an adult. B-ENT 2009;5 (3):179-82.

15) Lai PC, Wang JK, Liao SL. A case of dacryocystocele in an adult. Jpn J Ophthalmol 2004;48 (4):419-21.

16) Hong JH, Park CS, Lee DH, Cho KJ. Endoscopic marsupialization of nasolacrimal duct cyst complicated by cheek abscess in child without previous dacryocystitis. Korean J Otolaryngol-Head Neck Surg 2004; $47(11): 1188-91$

17) Lee HY, Kang JM, Joo YH, Hong SJ. A case of bilateral neonatal nasolacrimal duct cysts without dacryocystitis. Korean J OtolaryngolHead Neck Surg 2004;47 (2):182-4.

18) Ye MK, Lee YH, Lee SJ, Chang HW. Neonatal dacryocystitis associated with nasolacrimal duct cysts. Korean J Otolaryngol-Head Neck Surg 2001;44 (11):1216-9. 